\title{
Konsep Wasathiyyah M. Quraish Shihab dalam Tafsir Al-Misbah (Analisis Hermeneutika Hans-Georg Gadamer)
}

\author{
Nur Huda \\ Sekolah Tinggi Agama Islam Al-Anwar Sarang Rembang \\ Email:nurhuda@staialanwar.ac.id \\ Nur Hamid \\ Universitas Islam Negeri Walisongo Semarang \\ Email: elnur.hamid@walisongo.ac.id \\ Muhammad Khoirul Misbah \\ PP. Al-Anwar 3 Sarang Rembang \\ Email: rhiedyaferlyaart98@gmail.com
}

\begin{abstract}
The Islamic world, especially Indonesia, is increasingly experiencing moral and mental decline so that life is increasingly far from Islamic values. The emergence of extreme ideas and deviating from the truth also added to the atmosphere. It is wasathiyyah, a moderate attitude in various aspects of life that is slowly being echoed by Muslim scholars in various parts of the world and is used as a powerful formula in dealing with the above problems. This research tries to discuss the concept of wasathiyyah according to M. Quraish Shihab in Tafsir Al-Misbah. This research is classified as library research. The researcher used HansGeorg Gadamer's hermeneutic analysis. With this analysis knife, the researcher found that the Tafsir Al-Misbah was written as a response to M. Quraish Shihab's response to the phenomena and conflicts that occurred at that time. The fusion between Shihab's understanding of wasathiyyah with various horizons; text and society produces a concept of wasathiyyah which is a fair, balanced and tolerant attitude in life, both in world and in the hereafter.

Keywords: Gadamer's Hermeneutics, M. Quraish Shihab, Tafsir Al-Misbah, Wasathiyyah
\end{abstract}

\begin{abstract}
Abstrak
Dunia Islam, khususnya Indonesia semakin hari semakin mengalami kemerosotan moral dan mental sehingga kehidupannya semakin jauh dari nilai-nilai Islami. Munculnya
\end{abstract}


paham-paham ekstrem dan menyimpang dari kebenaran pun juga turut menambah keruh suasana. Adalah wasathiyyah, sebuah sikap moderat dalam berbagai sisi kehidupan yang perlahan digaungkan oleh para cendekiawan muslim di berbagai belahan dunia dan dijadikan sebagai formula ampuh dalam menghadapi problem di atas. Penelitian ini mencoba membahas konsep wasathiyyah menurut M. Quraish Shihab dalam Tafsir AlMisbah. Penelitian ini tergolong penelitian kepustakaan. Peneliti menggunakan analisis hermeneutika Hans-Georg Gadamer. Dengan pisau analisis tersebut, peneliti menemukan bahwa Tafsir Al-Misbah ditulis sebagai bentuk respon M. Quraish Shihab terhadap fenomena dan konflik yang terjadi pada masa itu. Peleburan antara pemahaman Shihab terhadap wasathiyyah dengan berbaga cakrawala;teks dan masyarakat menghasilkan suatu konsep wasathiyyah yang berupa sikap adil, seimbang dan toleran dalam kehidupannya, baik dalam urusan dunia maupun akhirat.

KataKunci: Hermeneutika Gadamer, M. Quraish Shihab, Tafsir Al-Misbah, Wasathiyyah

\section{Pendahuluan}

Tidak hanya berperan sebagai pedoman hidup, al-Qur'an berfungsi pula sebagai bagian dari kepercayaan warga muslim yang cukup bervarian. Di antaranya adalah al-Qur'an berfungsi sebagai obat dan penyelamat dari berbagai bahaya. Ia pula berfungsi sebagai spirit perubahan, pembela kalangan marjinal, penentang aksi lalim, serta masih banyak lagi fungsi dan peran al-Qur'an, menyelaraskan setiap kebutuhan mereka. Dengan demikian warga muslim telah mentransformasikan alQur'an serta berdialektika secara langsung dan menghadirkan al-Qur'an di tengahtengah masyarakat sebagai nilai yang senantiasa diaplikasikan dalam kehidupan sehari-hari (Huda and Albadriyah 2020:359).

Transformasi dan dialektika masyarakat muslim dengan al-Qur'an tentu saja didasarkan pada pemahaman yang tidak tunggal dari setiap individu. Pemahaman yang kemudian diaplikasikan di dalam kehidupan bermasayarakat akan berimplikasi pada dua hal, yakni sikap ekstrim dan moderat. Kedua sikap itu bertitik-tolak pada pemahaman dan penafsiran setiap individu. Sikap ekstrim lahir karena pemahaman seseorang terhadap al-Qur'an yang cenderung over-tekstual dan rigid atau over-rasional dan terlalu longgar yang keduanya akan berujung pada paham radikalisme dan leberalisme, sementara sikap moderat timbul dari pemahaman seseorang yang komprehensif dan kontekstual (HS and Hamid 2019a, 2019b).

Setidaknya terdapat dua faktor yang menjadi tantangan dunia Islam saat ini. Muklis Hanafi (dalam Zamimah 2018: 75-76) menjelaskan bahwa kedua faktor tersebut masing-masing berasal dari dalam dan dari luar. Faktor internal dunia Islam selain karena ketertinggalan dari berbagai sektor, baik ekonomi, politik, dan pendidikan, umat Islam juga terdikotomi oleh berbagai macam golongan yang 
berbeda pemahaman kegamaan. Pertama, sebagian umat Islam cenderung bersikap ekstrim dan kaku dalam memahami agama berikut hukum-hukum yang terkandung dan memaksa masyarakat muslim untuk mengaplikasikannya, bahkan terkadan tindakan anarkis dilakukan demi mewujudkan keinginnya. Kedua, sebagian umat Islam lainnya cenderung bersikap ekstrim dengan cara bersikap sangat longgar dalam memahami agama, bahkan cenderung menerima pemikiranpemikiran negatif dari budaya dan peradaban lain tanpa melakukan filter sebelmnya. Kedua sikap dan paham ini juga sering disebut dengan istilah ekstrim kiri dan kanan yang disebabkan oleh pemahaman yang keliru dan kurang komprehensif terhadap ajaran-ajaran Islam dan berakibat pada tindakan yang bertentangan dengan Islam itu sendiri (Adeni and Hamid 2020).

Faktor ekternal tantangan dunia Islam berasal dari tuduhan-tuduhan tidak mendasar dari golongan yang sejak awal tidak suka dengan agama Islam, khususnya dunia Barat, yang men-judge Islam sebagai agama teroris, agama anti kemajuan, agama yang memusuhi perempuan. Tentu saja, tuduhan itu berasal dari kesalahpahaman mereka ketika menilai Islam juga berasal dari minimnya pengetahuan mereka terhadap substansi ajaran-ajaran di dalam agama Islam.

Dalam konteks ini, momentum untuk meneguhkan pemahaman yang benar, moderat, dan toleran sangat nyata diperlukan. Hal ini dilakukan untuk menegaskan bahwa tuduhan-tuduhan miring terhadap Islam tidak lah benar dan bukan merupakan ajaran Islam. Ajaran Islam adalah ajaran yang menanamkan sikap moderat, tidak ekstrim kiri maupun kanan. Islam marupakan agama yang menjunjung kasih sayang, tidak hanya untuk muslim tapi juga non-muslim. Sehingga term "Islam rahmatan lil 'ālamīn" benar-benar bukan sebatas adagium yang hanya didengung-dengungkan, namun juga nyata direalisasikan di tengahtengah masyarakat.

Pada dasarnya sikap ekstrim kanan dan ekstrim kiri merupakan fenomena keagamaan yang bukan baru lagi dalam konteks kesejarahan Islam. Sebut saja yang pertama kelompok Khawarij yang disematkan kepada kelompok yang keluar dari sayyidina Ali bin Abi Thalib dan cenderung memberontak kepada kepemimpinan yang legal dan sah (Muhammad bin Abdul Karim al-Syihristani 1968: 114). Adapun karakteristik secara umum sebagaimana dijelaskan oleh (Harras n.d.: 264) adalah; 1) suka memberi label kafir kepada sebagian umat Islam yang berbuat dosa besar; 2) berkeyakinan bahwa iman tidak seseorang tidak mengalami perubahan alias stagnan dan tetap; 3) menjustifikasi sekaligus memperbolehkan adanya pemberontakan kepada penguasa zalim walaupun tidak nyata kekufurannya; 4) melabeli kafir terhadap muslim yang tidak menggunakan hukum Allah; dan 5) memiliki sifat dan sikap yang tergesa-gesa mengafirkan tanpa menimbang dan memperhaikan syarat-syarat dan konskuensinya. 
Dalam konteks kekinian, belum lama pelitian Ghozali (2020: 17) tentang pemilihan presiden tahun 2019 menunjukan adanya demokrasi model politik newKhawarij yang sifat dan karakteristiknya tidak jauh berbeda dengan Khawarij model lama. Hasil penelitian tersebut menunjukan bahwa new-Khawarij memakai model demokrasi agama yang otoriter dengan bercirikan ; 1) tidak menerima hasil pemilu yang sah; 2) menolak keputusan politik yang tidak sesuai harapan politiknya; 3) berdemo turun ke jalan atas nama persamaan politik dan hukum namun berkedok ingin mendirikan Khilafah.

Selain itu, belum begitu lama, keterpengaruhan siswa dan mahasiswa terhadap ideologi radikal melalui buku terbilang sangat memprihatinkan. Riset Rokhmad (2018: 45) menunjukan bahwa 48,9\% siswa Jabotabek mengamini aksi dan tindakan kekerasan. Sementara di tingkat perguruan tinggi, 65\% mahasiswa (2466 sampel) menyetujui diberlakukannya sweeping demi menegakan amar makruf nahi munkar.

Adapun kelompok kedua, ekstrim kiri, diwakili oleh kelompok Al-Mu'tazilah al-Judūd (new-Mu'tazilah) yang mengatasnamakan dan mengusung kebebasan tanpa batas di dalam Islam. Kelompok ini menyatakan bahwa Islam itu agama yang rasional dan senantiasa menyesuaikan perkembangan zaman. Islam tunduk pada budaya dan peradaban baru, termasuk menerima pemikiran, budaya dan peradaban Barat tanpa adanya penyaringan terlebih dahulu (Qadir 1999: 23). Kelompok ini biasa disebut sebagai kelompok dengan sikap atau pandangan yang liberal. Sudah menjadi rahasia umum bahwa Amerika Serikat melalui keputusan Mahkamah Agung tertanggal 26 Juni 2015 dengan dilakukan oleh lima Hakim telah melegalkan pernikahan sejenis atas nama hak asasi manusia dan kebebasan memilih jalan hidup. Bahkan Belanda terhitung sebagai negara yang lebih dahulu melegalkan perkawinan sejenis pada tahun 2001. Hingga saat ini terhitung ada sekitar 23 negara yang melegallkan perkawinan satu jenis (Rohman 2020: 54).

Indonesia berdasarkan UU. Perkawinan No.1/1974 secara jelas melarang dan tidak memberikan celah perkawinan sejenis. Namun demikian, kasus yang terjadi di Jember tahun 2017, yakni perkawinan Saiful Bahri (menyamar Ayu Puji Astutik) dengan Fadloli, menuia pro dan kontra. Walaupun mayoritas ulama melarang keras perbuatan tersebut, masih saja ada beberapa cendikiawan yang melegalkannya. Sebut saja Siti Musdah Mulia, guru besar di UIN Syarif Hidayatullah dengan lantang membolehkan praktik kawin sejenis dengan alasan ; 1) tidak adanya perbedaan antara lelaki dan perempuan, keduanya sama tanpa memandang apa pun, termasuk orientasi seksual; 2) ajaran Islam adalah menghormati kedaulatan manusia; dan 3) bahwa ajaran agama hanya melarang seksualnya, bukan orientasi seksual (Rohman 2020: 65).

Contoh kasus di atas menunjukan adanya sikap ekstrimis akan menyebabkan hancurnya tatanan, baik secara lengkup terkecil individu hingga negara dan dunia 
internasional. Bahkan sikap ekstrimis tersebut juga mengancam dan berdampak negatif pada agama Islam itu sendiri, yakni agama menjadi tertuduh negatif hanya karena beberapa oknum tidak tepat dalam memahami dan menafsirkan ajaranajaran di dalam agama Islam.

Al-Qur'an secara eksplisit banyak memaparkan pentingnya bersikap moderat, misalnya QS. Al-Maidah [5]: 77, QS. An-Nisa' [4]: 171, dan QS. Al-Isra'[17]: 29 dan 110. Allah SWT dalam QS. Al-Baqarah [2]: 143 memposisikan umat Islam sebagai umat yang moderat dan menjadi umat terbaik. Dengan demikian moderasi merupakan nilai pokok dalam ajaran agama Islam. Karakteristik ini merupakan solusi sekaligus formula dalam mengatasi persoalan-persoalan yang muncul belakangan ini, semisal radikalisame, fatanisme, liberalisme, takfir, yang tentunya memerlukan sikap proporsional dan pemahaman komprehensif yang termaktub dalam konsep wasathiyyah.

Di Indonesia, salah satu tokoh cendikiawan sekaligus mufasir yang dikenal dengan sikap moderatnya adalah M. Quraish Shihab. Melalui banyak karyanya, tokoh mufasir Indonesia ini dikenal sebagai ulama menjunjung tinggi persatuan bangsa di tengah pluralitas agama di Negara Kesatuan Republik Indonesia. Meski sempat dicap oleh beberapa kalangan sebagai tokoh Syi'ah, bahkan liberal, akan tetapi Beliau menolak dengan tegas tuduhan tersebut. Selain itu, mayoritas muslim menilai bahwa Beliau adalah representasi dari seorang mufasir kontemporer yang paling moderat dibandingkan dengan mufasir lain.

Tafsir al-Misbah merupakansalah satu dari sekian banyak karya tulis $\mathrm{M}$. Quraish Shihab yang masyhūr di kalangan masyarakat Indonesia. Secara garis besar, tafsir al-Misbah ini merupakan bentuk refleksi dari sikap dan pemikiran wasathiyyah Beliau dalam memahami ayat-ayat al-Qur' an dan menyikapi polemik keagamaan di masyarakat. Hal tersebut dapat dilihat dari salah satu penafsirannya pada QS. Al-Baqarah [2]:143. Dalam ayat tersebut Beliau menjelaskan tentang posisi umat Islam sebagai ummatan wasathan (umat pertengahan) dalam segi kehidupan. Secara lengkap Beliau mengatakan :

Pertengahan juga adalah pandangan umat Islam tentang kehidupan dunia ini: tidak mengingkari dan menilainya maya, tetapi tidak juga berpandangan bahwa kehidupan dunia adalah segalanya. Pandangan Islam tentang hidup adalah di samping ada dunia, ada juga akhirat. Keberhasilan di akhirat ditentukan oleh iman dan amal saleh di dunia. Manusia tidak boleh tenggelam dalam materialisme, tidak juga membumbung tinggi dalam spiritualisme, ketika pandangan mengarah ke langit, kaki harus tetap berpijak di bumi. Islam mengajarkan umatnya agar meraih materi-materi yang bersifat duniawi, tetapi dengan nilai-nilai samawi (Shihab 2002: 375-376)

Dari penafsiran tersebut, dapat dipahami bahwa dalam memandang kehidupan, Quraish Shihab selalu memperhatikan dan mempertimbangkan 
keadaan yang berada di dua kutub yang saling bersebrangan dan berlebihan, seakan hendak berkata bahwa jangan mengikuti dua kutub yang bersebrangan tersebut dan jangan pula meninggalkan kedua-duanya, namun hendaknya mengambil sebagian kecil dari kedua kutub tersebut dan menjadikannya sebagai penengah dari kedua kutub yang berlebihan tersebut.

Berdasarkan deskripsi di atas, peneliti tertarik untuk menganalisis makna wasatiiyyah secara komprehensif dengan bertumpu pada penafsiran M. Quraish Shihab dalam Tafsir Al-Misbah. Penelitian yang hendak peneliti lakukan ini adalah menganalisa penafsiran Quraish Shihab terhadap ayat-ayat wasatiyyah, yakni ayatayat yang di dalamnya termuat kata yang menggunakan kata dasar "وسط " berikut derivasinya dengan pendekatan hermeneutika Hans-George Gadamer.

Alasan peneliti memilih penafsiran M. Quraish Shihab karena Beliau merupakan cendekiawan muslim sekaligus seorang figur mufassir kontemporer yang dikenal sangat menjunjung tinggi nilai-nilai wasațiyyah, terlebih Beliau hidup di masa kontemporer saai ini, sehingga dengan memahami penafsiran Beliau tentang wasatiyyah, diharapkan akan mampu memunculkan pemahaman tentang konsep wasatiyyah yang benar-benar mampu menjadi solusi dalam menghadapi konflik dan permasalahan sosial kemasyarakatan maupun sosial keagamaan saat ini. Sementara alasan peneliti memilih teori hermeneutika Hans-George gadamer sebagai pisau analisis adalah karena konsep hermeneutika Gadamer menitikberatkan pada prinsip menafsirkan teks dari masa lalu untuk dipahami dan diaplikasikan di masa kini dengan pemahaman yang berdasarkan pada historisitas dan horison sang pengarang.

Pada dasarnya, kajian atau penelitian tentang wasathiyyah telah banyak diteliti. Namun demikian, masing-masing mempunyai karakteristik dan perbedaan baik dari aspek material maupun formal. Sebut saja penelitian Umam (2018) yang berjudul Konsep Islam Nusantara: Kajian Ayat-Ayat Multikultural Dalam Tafsir Al-Azhar Karya Hamka Dan Tafsir Al-Misbah Karya M. Quraish Shihab. Ia mengkaji tentang ayat-ayat multikutural dalam kerangka ke-Indonesia-an atau yang dikenal dengan Nusantara melalui karya dua mufasir Indonesia yang tidak diragukan lagi kepakarannya di bidang tafsir, yakni M. Quraish Shihab dan Hamka. Ia menegaskan bahwa ayat-ayat multikurtural erat kaitannya dengan Islam Nusantara yang notabene merujuk kepada ortodoksi madzhab Asyari dalam teologi, Syafi'i dalam fiqh, dan Ghazali dalam tasawuf. Ortodoksi Islam Nusantara tersebut benar-benar menumbuhkan karakter wasathiyyah, Islam moderat dan toleran.

Tesis Rahmah (2020) yang berjudul Moderasi Beragama dalam Al-Qur'an: Studi Pemikiran M. Quraish Shihab dalam Buku Wasathiyyah: Wawasan Islam tentang Moderasi Beragama menjelaskan secara spesifik buku tentang konsep moderasi beragama model Qurash Shihab. Dalam penelitiannya, peneliti 
berkesimpulan bahwa dalam beragama, moderasi ditandai dengan adanya kebijakan, keseimbangan dan ilmu pengetahuan. Selain itu, langkah utama dalam mengimplementasi moderasi agama adalah diwujudkan dengan sikap waspada, hati-hati, seimbang dalam kehidupan sehari-hari.

Selanjutnya adalah artikel Zamimah (2018) yang berjudul Moderatisme Islam dalam Konteks Ke-Indonesiaan (Studi Penafsiran Islam Moderat M. Quraish Shihab). Artikel ini mencoba membuktikan bahwa ajaran moderat telah diajarkan dalam tradisi Islam sejak lama. Pembuktian ini didasarkan pada penafsiran yang telah disampaikan oleh para ulama, khususnya para ulama modern di Indonesia yang secara spesifik ditujukan kepada model pemikiran Quraish Shihab. Salah satu yang menjadi perbedaan mendasar dalam kajian kali ini adalah bahwa penelitian Zamimah terbatas pada aspek pembahasan diksi dan kebahasaan yang dipakai dalam Tafsir Al-Misbah. Teknik analisis yang digunakan peneliti ini adalah mengeksplor makna yang tercantum di dalam Tafsir Al-Misbah sesuai dengan apa yang dipahami.Ia menganalisis dan menerangkan apa yang dimaksud dari masingmasing kalimat yang terdapat di dalam Tafsir tersebut. Selain itu, Penelitian ini tidak disertai dengan data terkait konflik kekinian yang dijadikan patokan untuk merumuskan konsep moderatisme Islam yang dapat diaplikasikan di Indonesia secara khusus.

Dari beberapa penelitian tersebut, kiranya tampak dengan jelas pembeda atau distingsi sekaligus substansi pada penelitian kali ini. Dari aspek objek formal, yakni berdasarkan pendekatan hermeneutika Gadamer dapat dikatakan penelitian ini belum pernah dilakukan oleh-peneliti-peneliti sebelumnya.

Penelitian ini tergolong penelitian kualitatif-deskriptif. Metode deskriptif dalam penelitian ini dimaksudkan untuk memahami dan memaparkan konsep wasathiyyah dalam kitab tafsir Al-Misbah karya M. Quraish Shihab. Tentu saja, tujuannya adalah memperoleh deskripsi secara datail mengenai konsep wasathiyyah model Quraish Shihab.

Terkait dengan teknik pengumpulan data, peneliti menggunakan metode simak dengan teknik sadap. Mahsun (2014: 92-93) menyatakan bahwa simak tidak hanya berkaitan dengan bahasa lisan, tetapi juga bahasa tulis. Dalam hal teknik sadap-tertulis, peneliti melakukan penyadapan bukan dengan orang yang sedang berbicara melainkan berupa bahasa tulis semisal naskah-naskah kuno, teks narasi, bahasa-bahasa pada massmedia. Adapun langkah-langkah dalam pengumpulan data adalah (1) membaca secara teliti dan cermat teks Tafsir AlMisbah dari awal hingga akhir, terutama ayat-ayat yang megandung term wasathiyyah, (2) menandai dan mencatat ulang teks narasi yang menjadi data dalam penelitian, dan (3) menginventarisir kata-kata atau ayat-ayat yang berhubungan dengan term wasathiyyah dengan menggunakan format inventarisasi data. 
Setelah semua data terkumpul, maka data tersebut dianalisis dengan cara (1) Mengidentifikasi sekaligusa menginventarisir data berupa penafsiran dari Tafsir AlMisbah yang memiki kesesuaian dengan tema yang dibahas, (2) Mengidentifikasi setting historis M. Quraish Shihab beserta setting historis penulisan Tafsir AlMisbah, (3) Mendeskripsikan dan menganalisis setting konflik yang disoroti dalam proses penulisan Tafsir Al-Misbah beserta setting konflik yang terkait dengan wasathiyyah, (5) Menginterpretasi data yang sebelumnya telah dianalisis dengan teori Hermeneutika Gadamer, dan (6) Membuat outline atas pembahasan yang sesuai dengan poin-poin penelitian.

\section{Pembahasan}

\section{Biografi Hans-Georg Gadamer}

Hans-Georg Gadamer dilahirkan di Marburg, Jerman 11 Februari 1900, dan tutup usia pada 13 Maret 2002. Ia merupakan salah satu filosof paling terkenal di Jerman dengan karya monumentalnya yang berjudul Wahrheit und methode. Studi pertamanya dimulai pada tahun 1918 di dua Universitas yang berbeda, yakni Universitas Breslau lalu pindah di Universitas Marburg. Di sana lah dia mulai mengenal filsafat melalui Nicolai Hartmanm, Ricard Honigswald, dan beberapa tokoh lainnya. Gelar Doktor filsafat berhasil diraih Gadamer pada tahun 1922 dengan judul "Das Wesen der Lust nach den Platonischen Dialogen" (The Essence of Pleasure according to Plato's Dialogues) (Irsyadunnas 2015: 127).

Karir puncak Gadamer diawali dengan pengangkatan Guru Besar di bidang filsafat yang diterima pada tahun 1939 di Universitas Leipzig. Selain itu, jabatan yang pernah diraih adalah menjadi Kepala Departemen Filologi dan Sejarah pada fakultas Filsafat. Direktur Institut Psikologi pun pernah dijabatinya. Pada tahun 1946, puncak karir akademiknya adalah pengangkatannya sebagai Rektor Universitas Leipzig. Dua kampus lain yang menjadi tempat ajarnya adalah Universitas Frankfrut dan Heidelberg masing-masing tahun 1948 dan 1949 dan pada tahun 1968 dia memutuskan untuk pensiun (Irsyadunnas 2015: 127).

\section{Gagasan Pemikirannya tentang Hermeneutika}

Salah satu tokoh yang banyak mempenaruhi Gadamer adalah Heideger. Pengaruhnya begitu besar sehingga Gadamer pernah menyatakan bahwa dia sangat berhutang kepada Heideger. Gagasan sejarah budaya dan seni sekaligus 
pendekatan hermeneutika Heideger benar-benar tidak bisa dipisahkan dari pembentukan dasar pemikiran hermeneutika Gadamer.

Dalam karya yang berjudul Wahrheit und methode, Gadamer menjelaskan secara komprehensif pemikiran hermeneutika ke dalam beberapa segmen. Di antaranya adalah konsep pemahaan teks. Konsep pemahaman menurutnya dapat diaplikasikan pada kondisi dan keadaan saat ini, walaupun pemahaman tersebut bertalian dengan dialektika, peristiwa sejarah, dan bahasa. Oleh sebab itu, pemahaman senatiasa memiliki posisi semisal posisi kita sekarang ini. Pemahaman sulit-untuk tidak mengatakan-tidak pernah bersifat ilmiah dan objektif. Alasan yang disampaikan adalah karena pemahaman bukan lah "mengetahui" dengan cara satatis dan di luar skema waktu, tetapi selalu dalam keadaan, tempat, kerangka, dan ruang mauun waktu tertentu yang disebut dengan sejarah. Baik pengalaman, bahasa, dan pemahaman, seluruhnya menyejarah (Sumaryono 2015: 81).

Pemahaman senantiasa berada dalam cakrawala dan konteks sejarah yang berubah. Itu lah sebabnya, mengapa interpretasi tidak pernah rigid, kaku, statis dan bersifat monolitik atau beraspek tunggal. Konstruksi pemahaman akan senantiasa mengikuti cakrawala yang selalu berubah. Pada akhirnya, pemahaman merupakan gabungan dari cakrawala yang beraneka ragam dan hubungan timbal balik antara konteks sejarah yang tidak tunggal. Dalam hal ini Gadamer menegaskan bahwa teks, baik kitab suci maupun undang-undang harus secara terus-menerus dan setiap saat dengan cara yang baru sekaligus berdasarkan situasi tertentu (Sumaryono 2015: 83).

Afective historis adalah teori yang dikembangkan Gadamer dalam memahami sebuah teks. Secara terperinci, terdapat empat langkah yang harus ditempuh seseorang jika ingin memahami sebuah teks.

Pertama, "Kesadaran Keterpengaruhan oleh Sejarah" (Wirkungsgeschichte). Gadamer menjelaskan bahwa ketika teks ingin ditafsirkan, maka seseorang harus sadar bahwa dirinya ternyata sudah terpengaruh oleh situasi dan kondisi hermeneutik yang mengitarinya, baik berupa kultur atau tradisi maupun pengalamam hidup. Oleh sebab itu, ketika sedang menafsirkan teks, penafsir mestinya sadar bahwa dia sedang berada pada posisi tertentu yang mampu mempengaruhi pemahamannya terhadap sebuah teks yang sedang ditafsirkan. Di sini lah Gadamer ingin menegaskan bahwa seseorang harus tahu bahwa dalam setiap proses pemahaman, pengaruh afective historis sangat kuat, entah dia 
menyadari atau tidak keberadaannya. Penafsir harus berusaha untuk mengatasi unsur subjektifitas dalam menginterpretasi sebuah teks. Namun demikian, Gadamer mengakui kondisi tersebut sangat lah sulit dihindari (Syamsudin 2011: 36).

Kedua, "Prapemahaman" (Vorverstandnis/Pre-understanding). Situasi hermeneutik yang mempengaruhi diri penafsir akan memunculkan konsep yang dinamakan dengan istilah pramemahaman. Kondisi ini merupakan sebuah keniscayaan dan proses awal bagi penafsir saat membaca sebuah teks. Keniscayaan itu pula yang menjadi maksud supaya penafsir bisa mendialogkan isi teks yang sedang diinterpretasi. Gadamer menyatakan bahwa tanpa prapemahaman, seorang penafsir tidak akan mampu memahami teks secara baik. Namun demikian, sikap terbuka dalam mengkritisi, merehabilitasi, dan mengoreksi pemahaman di saat penafsir menyadari bahwa teks yang dipahami tidak sesuai merupakan bagian dari prapemahaman yang tepat dan benar. Hasil koreksi dan rehabilitasi ini yang kemudian dinamakan dengan istilah "kesempurnaan prapemahaman". (Syamsudin 2011:37-38).

Ketiga, Peleburan Horison (Fusion of Horizon/Horizontverschmelzung). Tahap yang ketiga ini sangat erat kaitannya dengan tahap sebelumnya. Dengan kata lain penafsir harus sadar bahwa terdapat dua horison yang ditempuh olehnya, yakni horison teks (cakrawala pengetahuan) dan horison pembaca (cakrawala pemahaman). Kedua horison atau cakrawaka tersebut senantiasa hadir dalam proses memahami dan menafsirkan. Seorang penafsir harus menyadari bahwa tugasnya adalah medialogkan atau mengomunikasikan antara horison teks dan horison yang dimiliki penafsir ke dalam apa yang dimaksud Gadamer dengan istilah "lingkaran hermeneutika". Upaya ini dilakukan agar tidak terjadi ketegangan antara kedua horison tersebut. Dengan demikian, ketika seseorang membaca sebuah teks yang lahir di masa lampau, maka yang harus dilakukan pembaca adalah memerhatikan aspek horison historis, baik yang terkait dengan tempat kemunculan, pengungkapan, maupun penulisan sebuah teks. (Syamsudin 2011: 39).

Keempat, Penerapan (Anwendung/Application). Sudah menjadi keniscayaan bahwa penafsir harus benar-benar memerhatikan makna objektif dalam proses pemahaman sekaligus penafsiran teks. Langkah berikutnya adalah penafsir harus mampu menerapkan pesan teks kitab suci saat teks diinterpretasi. Dengan adanya 
kenyataan bahwa jarak antara kegiatan interpretasi dan masa munculnya teks sangat lah jauh, ditambah perbedaan kondisi ekonomi, politik, sosial yang melingkupi, hal itu semua yang menjadikan penafsir harus bisa menemukan "meaningful sense" sebagai sebuah pesan teks di samping juga penafsir harus mampu memperoleh makna objektifnya (Syamsudin 2011: 41). Dengan demikian, pada tahap ini penfsir diharapkan mampu menemukan makna tersurat dan makna terirat. Naser Hamid menamakan kegiatan tersebut dengan istilah "interpretasi makna cum maghza", sementara al-Ghazali menyebut istilah tersebut dengan term "al-ma’nā al-dhāhir" dan "al-ma'nā al-bāthin". Gadamer sendiri menyebut kedua term itu dengan istilah sinn (artu) dan sinnesgemaf (makna terdalam). Melalui analisis historis dan analisis linguistik sebagai analisis paling mendasar, konteks sejarah saat teks itu lahir dan konteks tekstual menjadi sangat penting untuk diperhatikan oleh setiap penafsir untuk menemukan dan menerapkan makna teks yang menjadi pesan teks kitab suci secara objektif.

\section{Biografi M. Quraish Shihab}

M. Quraish Shibah (selanjutnya dibaca Quraish) lahir Lotassalo, Sidenreng Rappang, Sulawesi Selatan, tepat pada hari Rabu 22 Safar $1363 \mathrm{H}$ atau bertepatan tanggal 16 Februari 1944 M. Ia merupakan putra keempat dari 12 bersaudara pasangan Abdurrahman Shihab (1905-1986) dengan Asma Aburisy. Nama Shihab sendiri merupakan marga dari golongan Alawiyin banyak dijumpai di Arab Hadrami, Yaman (Anwar, Siregar, and Mustofa 2015: 3-5). Ia lahir di lingkungan yang agamis dan taat. Bahkan sejak kecil, Quraish biasa ikut menemani sang ayah ketika sedang mengajar.

Ayahnya, Abdurrahman Shihab yang merupakan guru besar Tafsir dan pernah menjadi rektor IAIN Alaudin memiliki pengaruh besar dalam membentuk karakter dan kepribadian Quraish, bahkan juga terkait keilmuannya kelak (A. Shihab 1997: V). Ayahnya senatiasa mendorong Quraish dan saudara-saudaranya agar meraih pendidikan setinggi mungkin. Melalui ayahnya, Quraish secara intensif memperoleh pendidikan agama, baik yang berkaitan dengan al-Qur'an, tauhid, fiqh, akhlak dan lainnya. Semua itu berpengaruh besar pada horizon intelektual dan pemikirannya di masa mendatang (Junaidi 2012: 53).

Dimulai pendidikan dasar yang ada di desa sendiri, Quraish melanjutkan pendidikan tingkat menengah di kota Malang sekaligus menjadi santri di Pondok Pesantren Dārul Hadis al-Fiqhiyyah. Setelah itu dia melanjutkan studinya ke Mesir 
di Universitas Al-Azhar Fakultas Ushuludin jurusan Tafsir dan Hadis. Gelar Lc. berhasil diraih olehnya pada tahun 1967 . Sementara di fakultas yang sama, gelar M.A. berhasil diraih pada tahun 1969 dengan judul tesis I'jāz al-Tasyrì li al-Qứān al-Karīm. Gelar doktor berasil diraihnya pada tahun 1982 di Universitas yang sama dengan judul desertasi Nazm al-Durar li al-Biqā̉i; Tahqīq wa Dirāsah (Masduki 2009: 11-12).

Latar belakang keluarga yang agamis, kepribadian yang disiplin dan keciantaan sekaligus minat terhadap ilmu agama berikut latar belakang pendidikan yang dimiliki mengantarkan Qurash Shihab menjadi ahli tafsir ternama di Indonesia. Kesibukannya saat ini, selain menjabat Guru Besar di UIN Syarif Hidayatullah Jakarta, dia juga menjabat Direktur PSQ, Pusat Studi Al-Qur'an di Jakarta. Jabatan penting lain yang diperoleh du luar kampus di antaranya ketua Majlis Ulama Indonesia Pusat sejak 1984, Anggota Lajnah Pentashih Al-Qur'an sejak 1989, dan bahkan walaupun sebentar, ia pernah menjabat sebagai Menteri Agama pada Kabinet Pembangunan VII pada tahun 1998 dan pada tahun 1999 dia diangkat menjadi Duta Besar Luar Biasa untuk Mesir. Di tahun itu lah Qurasih mulai menulis Tafsir al-Mishbah, salah satu karya monumental yang dimilikinya (Zamimah 2018: 80).

\section{Tafsir Al-Misbah}

Pada dasarnya setiap karya tidak bisa lepas dari faktor melingkupinya. Faktor itu bisa bersifat internalmaupun eksternal. Hal itu pula yang dialami M. Quraish Shihab ketika hendak menyusun Tafsir Al-Mishbah. Beberapa kalangan sering memberi stimulus dan meminta supaya Quraish membuat sebuah tafsir mengingat kepakaran yang dimiliki sudah masyhur di telinga bangsa Indonesia. Bahkan Quraish sering menerima surat dari berbagai pihak supaya dirinya membuat sebuah karya ilmiah tentang tafsir "secara serius". (Said 2014: 182).

Keinginan kuat mengarang atau menulis tafsir sebenarnya jauh-jauh hari sudah menjadi agenda dan rencana M. Quraish Shihab. Bahkan dari pihak keluarga sering kali memotivasi dan mendukung beliau untuk segera merealisasikannya. Namun demikian, kesibukan dan agenda yang padat tidak memungkinkan bagi beliau untuk menindaklanjuti keinginan tersebut. Dalam salah satu kesepatan Quraish menyatakan bahwa aktifitas mengarang, apalagi karangan tafsir, memerlukan konsentrasi penuh dan terkadang perlu untuk mengasingkan diri (Anwar, Siregar, and Mustofa 2015: 281). 
Jabatan Duta Besar Luar Biasa untuk Mesir yang diterima M. Quraish Shihab pada tahun 1999, juga Somalia, dan Jibuti memberikan angin segar pada beliau untuk mencoba merealisasikan niatnya mengarang kitab tafsir. Hal itu dikarenakan bahwa dengan jabatan yang diterima itu, secara tidak langsung mengurangi rutinitas padat yang sering dijalani ketika berada di tanah air. Kondisi tersebut benar-benar dimanfaatkan untuk membulatkan tekad dalam menulis kitab tafsir yang sudah lama diidam-idamkan.

Penulisan tafsir ini dimulai pada saat Quraish berada di kota Saqar hari Jum'at 18 Juni 1999 M. Semula beliau hanya berkeinginan menulis tafsir dalam tiga jilid. Namun karena aspek kenikmatan yang dirasakan saat menyelami kalam Ilahi dan kenikmatan itu merasuk ke dalam jiwa atau spirit, pada akhirnya beliau mampu mengarang tafsir hingga 14 jilid yang berisi juz 1 hingga 29. Aktifitas mengarang tersebut beliau lakukan selama menjabat sebagai Duta Besar Mesir hingga akhir masa jabatan tahun 2002. Biasanya, waktu yang gunakan untuk menulis tafsir adalah setelah Subuh, saat di kantor, dan di waktu malam hari. Penulisan tafsir tersebut kemudian dilanjutkan dan disempurnakan ketika beliau kembali ke tanah air, tepat pada hari Jum'at tanggal 3 September, tafsir yang dinamai Al-Misbah rampung ditulis dengan total volume mencapai 15 Jilid (Anwar, Siregar, and Mustofa 2015: 282).

Perlu diketahui bahwa tafsir tersebut dinamakan dengan Al-Misbah, yang berarti lampu, lentera, atau alat penerang lainnya karena M. Quraish Shihab memiliki harapan supaya karya tersebut mampu menjadi penerang bagi orangorang yang membaca dan menjadi petunjuk hidup yang berasal dari al-Qur'an. Selain itu, Quraish memang cenderung menyukai hal-hal yang memiliki fungsi meneranngi. Oleh karenanya, sejumlah karya atau buku lain beliau namakan dengan Lentera Hati dan Pelita Hati.

Sebagaimana penjelasan sebelumnya bahwa tafsir Al-Mishbah merupakan tafsir lengkap 30 Juz yang berjumlah 15 jilid mulai dari surat Al-Fatihah hingga surat An-Nas. Adapun spesifikasi tafsir tersebut adalah sebagai berikut :

a. Jilid 1 terdiri dari QS. Al-Fatihah-QS. Al-Baqarah

b. Jilid 2 QS. Ali Imran-QS. Al-Nisa'

c. Jilid 3 berisi QS. Al-Mäidah

d. Jilid 4QS.Al-An'ām

e. Jilid 5 QS.Al-A'räf-QS.Al-Taubah 
f. Jilid 6 QS. Yunus-QS. Al-Ra'd

g. Jilid 7 QS. Ibrāhim-QS. Al-Isrā’

h. Jilid 8 QS. Al-Kahfi-QS. Al-Anbiyā'

i. Jilid 9QS. Al-Hajj-QS. Al-Furqān

j. Jilid 10 QS. Syu'arā'-QS. Al-Ankabūt

k. Jilid 11 QS. Al-Rūm-QS. Yāsīn

1. Jilid 12 QS. Shaffät-QS. Al-Zuhrüf

m. Jilid 13 QS. Al-Dukhān-QS. Al-Wāqiah

n. Jilid 14 QS. Hadìd-QS. Al-Mursalāt

o. Jilid 15 berisi Juz ‘Amma

Secara umum sitematika tafsir Al-Misbah menggunakan langkah-langkah sebagai berikut : (1) Penafsiran diawali dengan mengurai detail permasalahan terkait surat yang dikaji, misalnya terkait jumlah ayat, nama-nama lain surah, tujuan utama surat, dan tema-tema pokok kajian surah; (2) Mengkaji ayat demi ayat dalam setiap surat. Ayat-ayat yang memiliki tema pokok yang sama ditulis teks Arabnya dalam satu kelompok sesuai urutan penomoran ayat, kemudian ayat-ayat tersebut diterjemahkan ke dalam bahasa Indonesia. Di bawah terjemah diberi penafsiran yang mengeksplorasi secara luas atas ayat-ayat tersebut.

Ayat-ayat yang Berisi Term Wasathiyyah

Berdasarkan penelusuran peneliti terhadap ayat-ayat al-Qur'an dengan menggunakan aplikasi Zekr versi 1.1.0, peneliti menemukan lima ayat dari hasil pencarian yang menggunakan kata kunci "وسط" yang merupakan bentuk kata dasar dari wasațhiyyah. Berikut ini adalah kelima ayat hasil pencarian yang peneliti rangkum dalam table berikut ini :

\begin{tabular}{|c|c|c|c|}
\hline No & Surah & Ayat & \\
\hline 1 & QS. Al-Ādiyāt[100]: 5 & فَوَسَطَنْنَ بِهِه جَمَمًْا & \multirow{2}{*}{ Makkiyah } \\
\hline 2 & QS. Al-Qalam [68]: 28 & 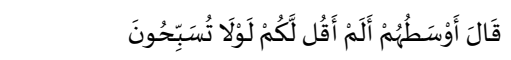 & \\
\hline \multirow[t]{4}{*}{3} & QS. Al-Maidah [5]: 89 & 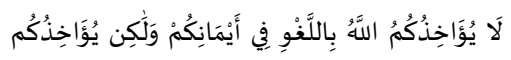 & \\
\hline & & 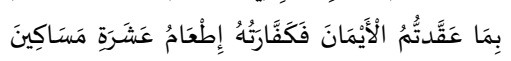 & \\
\hline & & 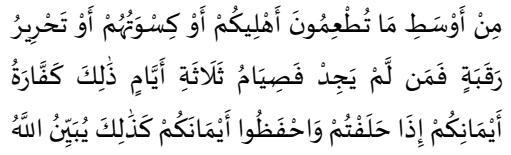 & Madaniyyah \\
\hline & & لَكُمْ آيَاتِِِه لَعَلَّكُمْ تَشْكُكُرونَ & \\
\hline
\end{tabular}




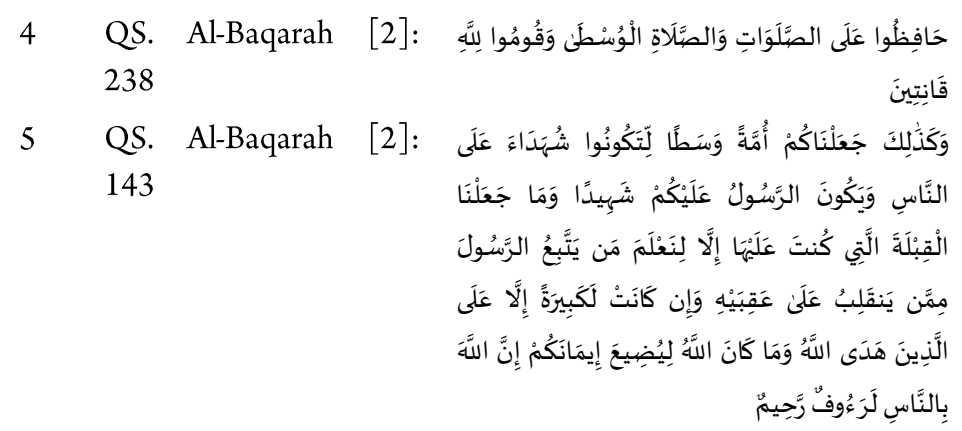

\section{Konsep Wasathiyyah dalam Tafsir Al-Misbah Pespektif Hermeneutika Gadamer}

\section{Horizon M. Quraish Shihab sebagai Penafsir}

Sebagaimana telah dijelaskan pembahasan sebelumnya, bahwa M. Quraish Shihab menghabiskan banyak waktu studinya di Universitas Al-Azhar pada Fakultas Ushuluddin jurusan Tafsir-Hadis. Semasa Al-Azhar, Shihab banyak bertalaqqi dengan sejumlah guru. Namun, dari sekian banyak guru yang pernah ia temui, dapat dikatakan bahwa Syaikh Abdul Halim Mahmud—pengarang kitab alTafsìr al-Falsafí fì al-Islām) — lah yang paling banyak memberikan pengaruh bagi Shihab. Persinggungan Shihab dengan Syaikh Abdul Halim Mahmud ini membawa dampak besar pada logika berfikir Shihab, terlebih dalam bidang tafsir. Pandangan-pandangan Syaikh Mahmud tentang hidup dan keberagaman diakui Shihab telah memberikan pengaruh tersendiri baginya, sehingga dengan pengaruh tersebut membuat Shihab kelak menjadi seorang intelektual dan mufasir yang memiliki pandangan moderat dan tidak anti terhadap keberagaman yang ada di sekelilingnya.

Tafsir Al-Misbah juga ditulis ketika Shihab berada di Al-Azhar Mesir pada kurun waktu 1999-2002 M. namun bukan sebagai mahasiswa, melainkan ketika menjadi Duta Besar untuk Mesir. Shihab menulis Tafsir ini dengan memanfaatkan perpustakaan lengkap yang dimiliki Al-Azhar untuk mencari rujukan yang diperlukan. Dapat dikatakan, bahwa Tafsir Al-Misbah ini lahir dalam balutan nuansa keilmuan Al-Azhar yang terkenal sebagai pusat peradaban keilmuan Islam moderat. Hal ini dikarenakan bahwa keterpengaruhan Shihab pada pandanganpandangan Syaikh Abdul Halim Mahmud yang merupakan ikon serta gurunya di program Tafsir-Hadis di Al-Azhar banyak mengilhami pandangannya ketika dalam 
proses penulisan tafsirnya. Pandangan-pandangan Syaikh Abdul Halim Mahmud yang mencoba mencari titik temu dalam keberagaman telah mengambil bagian besar pemikiran Shihab dalam penafsirannya.

Dalam kaitannya dengan penelitian ini, Tafsir Al-Misbah merupakan satu dari sekian karya tafsir kontemporer yang ramai dikaji oleh sejumlah peneliti. Secara Global, Tafsir Al-Misbah mulai ditulis pada penghujung abad ke-20 dan selesai pada awal abad ke-21. Pada masa ini terdapat banyak kajian Islam yang bergejolak di hampir seluruh dunia dalam tema dan slogan puritanisme Islam serta istilah ajakan kembali kepada Al-Qur' an dan Hadis dan beberapa kajian terhadap permasalahan-permasalahan sosial-agama kontemporer yang sedang berkembang di tengah masyarakat, seperti isu-isu gender dan lain-lain. Di lain sisi, sejumlah umat Islam, khususnya di Indonesia, belum memiliki bekal yang cukup untuk dapat memahami secara benar dan komprehensif-bahkan untuk sekedar mengikuti perkembangan-mengenai gejolak kajian tersebut, sehingga hal tersebut mengakibatkan banyak umat Islam terpengaruh begitu saja akan seruan puritanisme tersebut. Hal itu disebabkan masih minimnya minat masyarakat terhadap kajian-kajian tentang agama yang membahas tentang metode berhukum dalam agama. Kalau pun ada, hanya terbatas pada kajian produk jadi;fiqih yang stagnan. Selain itu, di saat yang sama masyarakat Indonesia telah disuguhkan dengan berkembangnya terjemah al-Qur' an, yang oleh kebanyakan orang dinilai sudah cukup sebagai bekal dalam memahami al-Qur' an (Siradj and Haerudin 2015: 51-53).

Keadaan yang demikian juga disebabkan umat Islam di Indonesia sedang terlena dengan merebaknya sebuah metode bacaan al-Qur' an yang dilagukan, atau yang sering disebut dengan tilāwah. Masyarakat mulai terpanggil untuk belajar alQur' an, akan tetapi bukan untuk mengkaji isi dan kandungannya, melainkan hanya untuk belajar bagaimana melantunkan ayat al-Qur' an yang indah sesuai irama lagu yang berlaku. Kondisi inilah yang pada perkembangannya melahirkan suatu ajang perlombaan tilawah al-Qur'ān, membaca al-Qur' an dengan irama sehingga menarik para masyarakat untuk menekuni cara membaca al-Qur' an yang indah dan merdu.

Sebagai langkah analisis awal dalam penelitian ini, peneliti memberikan asumsi bahwa Tafsir Al-Misbah ini ditulis oleh Shihab sebagai reaksi terhadap situasi dan 
kondisi yang dialami Shihab waktu itu. Asumsi ini didasarkan pada pernyataan Shihab :

Masyarakat dewasa ini pun mengagumi al-Qur'an. Tetapi, sebagian kita hanya berhenti dalam pesona bacaan ketika dilantunkan, seakan-akan kitab suci ini hanya diturunkan untuk dibaca. Memang, wahyu pertama memerintahkan membaca Iqra' bismi rabbika, bahkan kata Iqra' diulanginya dua kali, tetapi ia juga mengandung makna teliti lah, dalami lah, karena dengan penelitian dan pendalaman itu manusia dapat meraih kebahagiaan sebanyak mungkin (M. Q. Shihab 2002: X).

Pernyataan tersebut setidaknya memiliki dua gambaran. Pertama, pernyataan Shihab ini diungkapkannya setidaknya berangkat dari situasi dan kondisi yang terjadi di sejumlah masyarakat saat itu. Mereka terjebak dalam ambisi untuk belajar membaca al-Qur'an yang indah tanpa dibarengi dengan memahami isi kandungannya. Kedua, sebagai wujud kontra-produktif, pernyataan Shihab tersebut merupakan bentuk pra-struktur pemahaman yang lahir berdasarkan pengalaman Shihab di kehidupan bermasyarakat. Ungkapan yang diutarakan Shihab tersebut menunjukkan bahwa dia selaku pengarang, pada saat prapenyusunan Tafsir Al-Misbah telah melakukan pengamatan terlebih dahulu terhadap keadaan yang terjadi. Penilaiannya atas ketidakcocokannya dengan kondisi yang sedang terjadi tentunya didasarkan atas berbagai pertimbangan yang berangkat dari ilmu pengetahuannya yang mendalam dan pengalamannya yang luas.

Dengan keluasan pengetahuan dan pengalaman Quraish Shihab serta pandangannya terhadap zamannya sehingga Tafsir Al-Misbah ini ditulis mengandung hubungan hermeneutis, yakni terbentuknya "peleburan horizon" (fusion of horizon) antara horizon pandangan Shihab yang dimulai dari fase pra-struktur pemahamannya yang diperoleh dari guru-gurunya dan situasi sosial kesejarahan masyarakat pada saat itu. Pada fase peleburan horizon ini, tidak menutup kemungkinan juga terdapat prose percampuran berbagai horizon pada lingkup pemahaman Shihab, pemahaman guru-gurunya, dan pemahaman masyarakat. Dengan adanya peleburan berbagai horizon tersebut, terjadilah dialog antara Shihab dengan horizon-horizon di luar dirinya. Berkat adanya dialog antar horizon tersebut, maka 
didapati lah sebuah pengalaman hermeneutis oleh Shihab yang kemudian membuatnya memunculkan karya tafsir yang dinamainya dengan Tafsir Al-Misbah.

\section{Horizon Teks Tafsir Al-Misbah}

Sebuah teks yang telah tersebar luas di publik dengan sendirinya tidak lagi menjadi hak pribadi pengarang. Hal ini dikarenakan esensi dari makna teks adalah bersifat dinamis, artinya makna teks dapat dipahami oleh setiap pembacanya dalam setiap lintas masa dengan pemahamannya sendiri. Makna teks tidak dapat dikendalikan oleh pengarangnya, karena pengarang tidak memiliki kewenangan untuk menguasai makna teks secara penuh. Konsekwensinya, keaslian makna teks tidak dapat diraih. Meski demikian, keadaan ini tidak serta merta menjadikan pemahaman terhadap teks menjadi selalu subjektif (Amertawengrum 2010: 1-2). Keadaan yang demikian ini disebabkan karena pemahaman terhadap suatu teks akan selalu selalu diliputi oleh pengaruh kesejarahan yang berasal dari tradisi pembaca beserta tradisi pengarang, sehingga proses memahami teks diartikan sebagai kesepahaman yang tidak menutup kemungkinan baik pembaca atau penafsir akan membentuk makna sendiri dari hasil "memahamie yang berbeda dari pemahaman pengarang.

Secara garis besar, teks tafsir Al-Misbah merupakan akumulasi interpretasi Quraish Shihab terhadap ayat-ayat al-Qur' an dalam menanggapi fenomena sosialkeagamaan pada waktu itu. Dalam pendahuluan Tafsir Al-Misbah, Shihab mengatakan bahwa seakan-akan al-Qur'an hanya diturunkan untuk dibaca. Ungkapan ini menjadi momen prasangka Shihab yang timbul sebagai dampak dari pandangannya atas keadaan sosial saat itu.

Bersamaan dengan adanya tahap prasangka tersebut, momentum pra-struktur pemahaman juga mengambil tempat dalam usahanya untuk melihat realitas. Berbekal pengetahuan dan berbagai pengalaman yang dimilikinya, Shihab mencoba menawarkan suatu pemikiran dan sikap yang sesuai dengan nilai-nilai ajaran Islam dalam menghadapi problem fenomena yang sedang terjadi. Oleh karena itu, mengetahui konsep realitas yang dijalani sangat urgen. Karena jika seorang pengarang tidak tahu menahu terhadap konsep realitas yang dihadapinya, maka sudah dipastikan pra-struktur pemahaman tidak akan muncul.

Dari adanya unsur horizon masyarakat, prasangka dan pra-struktur pemahaman tersebut, maka terjadilah peleburan antar horizon, yakni horizon 
pemahaman Shihab, ajaran dari guru-gurunya dan horizon masyarakat. Fase peleburan horizon-horizon tersebut disebut sebagai momentum "memahami" atau "kesepahaman". Dalam tahap ini, terjadilah proses "memahami" oleh Shihab perihal bagaimana hidup yang sesuai dengan ajaran al-Qur' an yang dititikberatkan pada aspek sosial-keagamaan. Semua hasil pemahaman Shihab tersebut kemudian dituangkan ke dalam penafsirannya yang terangkum secara keseluruhan dalam Tafsir Al-Misbah.

\section{Historisitas Turunnya Ayat-Ayat Term Wasațiyyah (Al-Baqarah: 143)}

Dalam ayat ini terdapat penggalan kata " ummatan wasațan. Kata wasațan inilah yang mengilhami munculnya istilah wasatiyyah (M. Q. Shihab 2019: 6). Dalam berbagai literatur tafsir, kata wasat dalam konteks ayat ini memiliki orientasi makna "khiyār wa Ajwad" (pilihan dan terbaik). Jadi, ummatan wasațan dapat dimaknai dengan "umat pilihan dan terbaik". Pemaknaan ini diamini oleh para mufasir, salah satunya adalah Ibnu Kathir (1999: 454). Quraish Shihab (2002a: 415) juga senada dengan pemaknaan ini, hanya saja beliau menambahkan bahwa pemaknaan wasat juga dapat dimaknai dengan "pertengahan" yang menjadi "bagian dari dua ujung". Menurutnya, pemaknaan ini (pertengahan) tidak bertentangan dengan pemakaan yang telah disebut sebelumnya. Shihab memberikan analogi, bahwa setiap perkara yang dianggap baik merupakan pertengahan dari dua ujung sisi ekstrem yang saling bertolak belakang. Misal, kedermawanan merupakan pertengahan dari sifat kikir dan boros (M. Q. Shihab 2002b: 233). Dengan demikian, yang dimaksud ummatan wasatan sebagai umat pertengahan adalah umat yang selalu menghindari sikap ekstremitas.

Konteks dan topik pembahasan ayat ini berkenaan erat dengan ayat sebelumnya. Ayat yang diturunkan pada periode Madinah ini berperan sebagai jawaban yang diberikan Allah kepada nabi Muhammad dalam menanggapi tudingan miring dan cemoohan orang Yahudi terkait pergantian kiblat umat Islam. Ucapan orang Yahudi tersebut terekam jelas dalam surah al-Baqarah ayat 142:

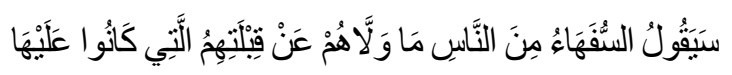

Orang-orang yang kurang akalnya diantara manusia akan berkata: "Apakah yang memalingkan mereka (umat Islam) dari kiblatnya (Baitul Maqdis) yang dahulu mereka telah berkiblat kepadanya?" 
Ucapan orang-orang Yahudi ini bermaksud menyerang keteguhan hati umat Islam secara tidak langsung dengan menyoal dan mempertanyakan tentang kiblat salat umat Islam yang berubah-ubah yang pada awalnya mengarah ke Ka'bah, kemudian beralih mengahadap Bait al-Maqdis, atau tadinya mengarah ke Bait alMaqdis, kemudian kembali lagi ke Ka'bah. Orang-orang Yahudi beranggapan bahwa pergantian kiblat tersebut dikarenakan adanya kekeliruan dari Nabi Muhammad, atau kemungkinan Nabi Muhammad hanya mengikuti hawa nafsunya untuk kembali menghadap ke Makkah karena kerinduannya terhadap kampung halamannya di Makkah yang telah ditinggalkannya sejak hijrah ke Madinah. Hasutan orang-orang Yahudi tidak hanya berhenti disitu, dengan adanya perubahan kiblat ibadah umat Islam mereka mengatakan bahwa ibadah (salat) yang telah dilakukan umat Islam dahulu ketika menghadap Ka'bah atau Bait alMaqdis tentu juga batal dan tidak ada pahalanya lagi. Atas berbagai tuduhan yang dilancarkan orang-orang Yahudi tersebut Allah kemudian memberikan jawaban untuk membantah tuduhan-tuduhan orang Yahudi dan bermaksud meneguhkan hati umat Islam atas hasutan-hasutan yang dilancarkan orang-orang Yahudi tersebut. Jawaban pertama disampaikan secara langsung dalam potongan ayat selanjutnya, yakni:

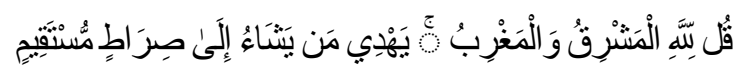

Katakanlah: "Kepunyaan Allah-lah timur dan barat; Dia memberi petunjuk kepada siapa yang dikehendaki-Nya ke jalan yang lurus".

Maksudnya, segala arah adalah milik Allah. Allah berkuasa dan mengatur segala hal yang berada diseluruh penjuru arah. Oleh karena itu, ke arah mana pun seseorang menghadap dalam beribadah, jika hal tersebut telah diperintahkan Allah, maka dia akan "menemukan" Allah di sana. Jadi, salat yang dijalankan umat Islam, baik menghadap ke Ka'bah atau ke Bait al-Maqdis, itu sah-sah saja dan bukan merupakan pekerjaan yang sia-sia karena itu merupakan perintah dari Allah (M. Q. Shihab 2002a: 413).

Selanjutnya, Allah memberikan jawaban lain dalam ayat selanjutnya, yakni pada ayat 143. Ringkasnya, isi dari ayat 143 adalah Allah menyatakan bahwa umat Islam ini merupakan umat yang telah dipilih Allah sebagai umat pilihan dan terbaik (ummatan wasațan). Hal ini dikarenakan umat Islam merupakan umat yang dibimbing oleh Nabi paling mulia, yakni Nabi Muhammad. Dengan mengikuti ajaran-ajaran yang disampaikan Nabi Muhammad, maka umat Islam akan 
mendapati berbagai sifat mulia dan budi luhur dalam ajaran yang disampaikan Nabi Muhammad. Dengan bimbingan dari Nabi Muhammad tersebut, umat Islam akan senantiasa mampu mendapat petunjuk dalam menghadapi dan menyelesaikan berbagai permasalahan dalam kehidupannya dengan baik dan sekaligus menjadi teladan bagi umat-umat lain. Terkait pemindahan kiblat hanyalah sebagai ujian dari Allah untuk mengukur seberapa besar ketaatan umat Islam dalam menerima dan menjalankan perintah Allah dengan sukarela. Karena, jika mereka benar-benar taat menjalankan perintah Allah yang disampaikan melalui Nabi Muhammad, maka ia akan mengikutinya secara sukarela meskipun hal tersebut sangat memberatkan dirinya dan ini merupakan salah satu cerminan dari sifat ummatan wasațan. Jika mereka menyalahi perintah Allah tersebut karena terpengaruh hasutan orang-orang Yahudi, maka mereka telah tergelincir dari jalan yang benar dan lurus, karena telah menyimpang dari perintah Allah.

\section{Historisitas Turunnya Ayat-Ayat Term Wasațiyyah (Al-Baqarah: 238)}

Secara lahiriyyah, ayat tersebut berisi sebuah perintah kepada umat Islam untuk benar-benar menjaga salat fardlu lima waktu, terlebih salat wusțā. Terkait apa itu salat wusțā para mufassir telah menyampaikan pendapat-pendapatnya yang berbeda-beda dalam berbagai literatur kitab tafsir. Namun dalam hal ini tidak akan dibahas perbedaan pendapat tersebut.

Historisitas turunnya surat al-Baqarah ayat 238 ini dilatarbelakangi suatu fenomena yang terjadi di masa Rasulullah, di mana pada saat itu ketika dilaksanakannya salat jamaah di tengah siang hari bersama Rasulullah banyak dari sahabat yang tidak hadir berjamaah karena letih atau masih sibuk dalam aktivitasnya. Keadaan demikian ini menjadikan banyak dari sahabat yang malas karena keletihan atau lupa karena kesibukannya untuk menjalankan salat, terlebih salat berjamaah dengan Rasulullah. Karena fenomena tersebutlah, Allah mengingatkan umat Islam untuk tetap menjaga salat fardlu, terutama salat wusțā meskipun sedang dalam kesibukan atau rasa lelah yang sangat. Rekam jejak penurunan ayat ini dapat ditelusuri di Musnad Ahmad dalam sebuah riwayat yang bersumber dari Zayd bin Thābit nomor 21595 :

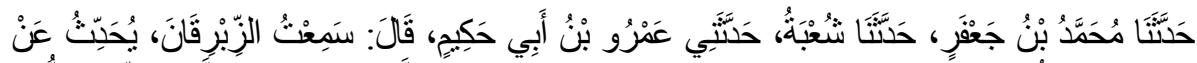

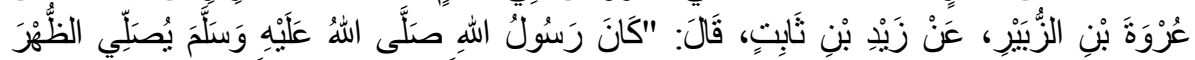

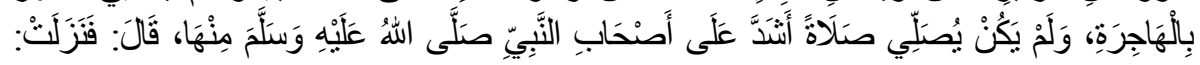




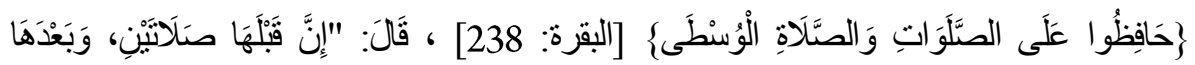

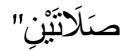

Dalam konteks ayat tersebut, kata wusțā dapat dipahami sebagai suatu yang berat dilakukan dan perlu mendapat perhatian dan pemeliharaan yang lebih, karena jika tidak demikian maka potensi terabaikannya akan menjadi lebih besar.

Historisitas Turunnya Ayat-Ayat Term Wasatiiyyah (Al-Mã'idah: 89)

Kata yang perlu digarisbawahi dalam ayat ini adalah redaksi أو (awsatii) yang merupakan salah satu bentuk derivasi dari gَ wasața. Sebelum memahami arti kata awsat dalam ayat ini, kiranya perlu diketahui sisi historisitas penurunan ayat ini dan kesinambungan dengan ayat sebelumnya.

Ayat 89 surah al-Mā'idah masih memiliki hubungan dengan dua ayat sebelumnya, yakni ayat 87 dan 88 , baik dalam hubungan sabab al-nuzūl maupun alur pembahasan. Dimulai dari ayat 87 , yakni di dalamnya disampaikan pesan terkait larangan melampaui batas dalam menjalankan agama, seperti mengharamkan sesuatu yang sebenarnya adalah haram. Lebih lengkapnya redaksi ayat ini adalah sebagai berikut:

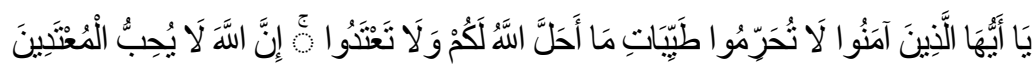

Hai orang-orang yang beriman, janganlah kamu haramkan apa-apa yang baik yang telah Allah halalkan bagi kamu, dan janganlah kamu melampaui batas. Sesungguhnya Allah tidak menyukai orang-orang yang melampaui batas.

Konteks turunnya ayat ini adalah berkenaan dengan kejadian yang dialami oleh beberapa sahabat. Didapati sejumlah sahabat yang berkeinginan kuat agar dapat fokus hanya untuk ibadah kepada Allah. Untuk mewujudkan hal tersebut, mereka bersumpah untuk tidak pernah menggauli istri mereka, bahkan tidak ingin menikah, mengharamkan mengonsumsi makanan-makanan yang mengenyangkan, dan bahkan mereka hendak memotong kemaluan mereka agar tidak memiliki hawa nafsu lagi. Hal itu mereka lakukan dengan tujuan agar dapat fokus untuk beribadah tanpa tercampuri oleh syahwat dunia sedikit pun (Al-Suyūțī n.d.: 84-85). Kemudian, turun lah ayat 87 ini untuk memperingatkan mereka bahwa apa yang mereka lakukan itu tidak lah benar. Bahkan Rasulullah juga 
memberikan teguran kepada mereka. Nabi mengatakan: "Aku adalah orang yang paling bertakwa dari kalian semua, tetapi aku melakukan salat malam dan aku juga tidur, aku berpuasa dan aku juga berbuka, dan aku juga menikah. Siapa saja yang enggan mengikuti cara hidupku ini, maka dia bukanlah termasuk dari golongan umatku".(HR. Bukhari dan Muslim).

Lalu pada ayat 88, secara umum Allah menegaskan kepada umat Islam, bahwa apa yang telah dianugerahkan Allah kepada manusia, maka nikmatilah itu semua sesuai selera masing-masing selagi itu memang diperbolehkan (dihalalkan) oleh agama. Jangan pernah sekali-kali bertindak melampaui batas seperti yang telah disinggung di ayat sebelumnya.

Lalu pada ayat 89, Allah memberi solusi bagi mereka yang dahulunya sudah terlanjur bersumpah untuk tidak menikah dan lain sebaginya, maka batalkanlah sumpah itu Jika mereka mengucapkan sumpahnya yang dulu itu dalam hatinya tidak memaksudkan bersumpah, maka membatalkannya tidaklah mengapa dan tidak terdapat hukuman. Namun jika mereka mengucapkan sumpah dan hatinya juga memkasudkan ucapan tersebut sebagai sumpah, maka dengan membatalkannya akan mendapat ketentuan hukuman (kafarah), yakni memberi makan sepuluh orang miskin dengan makanan pertengahan yang biasa diberikan kepada keluarganya atau memberi pakaian kepada mereka, atau memerdekakan budak, atau berpuasa selama tiga hari.

Itulah konteks dan historisitas turunnya surah al-Mā'idah ayat 89.

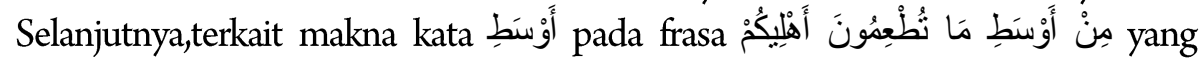
terdapat dalam ayat 89 , para ahli tafsir berbeda pendapat dalam menentukan maknanya. Ada yang memahaminya sebagai pertengahan dan ada yang memahaminya sebagai yang terbaik. Namun, Quraish Shihab menyatakan bahwa pendapat yang mengatakan bermakna pertengahan ini yang lebih unggul (M. Q. Shihab 2002b: 233).

\section{Historisitas Turunnya Ayat-Ayat Term Wasatiyyah (Al-Qalam: 28)}

QS. Al-Qalam : 28 ini masih memiliki keterkaitan pembahasan dengan ayatayat sebelum dan sesudahnya, yakni ayat 17 sampai ayat 33. Dalam ayat 17-33 surah al-Qlam diceritakan tentang kisah sekelompok pemuda yang durhaka karena keangkuhan mereka yang merasa sudah memiliki harta yang banyak dan kebun yang di dalamnya terdapat pepohonan yang buahnya melimpah namun mereka berencana untuk tidak menyedekahkan sebagian harta mereka kepada fakir- 
miskin. Karena keangkuhan mereka itu, akhirnya Allah memberikan balasan berupa dibinasakannya kebun yang mereka miliki beserta isinya.

Dari sisi historisitas penurunan ayat, ayat 17-33 surah al-Qalam diturunkan Allah untuk membalas ucapan Abu Jahl ketika perang Badar. Ucapan Abu Jahal tersebut adalah "Tangkaplah mereka (kaum muslimin) dan ikatlah dengan tambang, tapi jangan dibunuh". Maksud ucapan Abu Jahal adalah ia ingin memberikan siksaan bagi mereka yang telah membelot dari kaum Quraish Makkah dan mengikuti Nabi Muhammad dan setelah itu, ia akan membunuh mereka (Al-Suyūți n.d.: 201). Maksud konteks isi ayat yang diturunkan ini dengan historisitas penurunannya adalah Allah hendak menyampaikan bahwa apa yang diucapkan dan diharapkan Abu Jahal tersebut tidak akan terjadi seperti kisah gagalnya sekelompok pemuda yang hendak memetik buah di kebunnya, tapi sebelum itu terlaksana ternyata kebunnya sudah binasa terlebih dahulu.

Dalam rangkaian kisah yang disebutkan di surah al-Qalam ayat 17-33, terdapat satu kejadian di mana sekelompok pemuda tersebut akhirnya mengakui kesalahan mereka. pengakuan mereka ini karena sebelumnya diingatkan oleh salah seorang di antara mereka yang lebih baik pikirannya. Al-Qur' an menyebut orang yang mengingatkan ini dengan أَّْسَطُطُهْ Mayoritas mufasir sepakat bahwa yang dimaksud kata awsațuhum dalam konteks ini adalah orang paling adil, yang paling baik pemikirannya. Maka dapat dipahami, bahwa orang yang dimaksud oleh redaksi awsațuhum adalah orang yang paling bijaksana dan sadar bahwa apa yang direncanakan oleh teman-teman pemuda sekelompoknya adalah hal yang salah dan tidak terpuji. Oleh karena itu, di lanjutan ayat ini, al-Qur' an menyebutkan perkataan pemuda tersebut, Bukankah aku telah mengatakan kepadamu, hendaklah kamu bertasbih (kepada Tuhanmu)?".

\section{Historisitas Turunnya Ayat-Ayat Term Wasațiyyah (Al-Ādiyāt: 5)}

Surah al-'Ádiyāt, menurut suatu riwayat gharīb yang disandarkan kepada Ibnu 'Abbas, ini diturunkan berkenaan dengan kekhawatiran Rasulullah. Pada suatu saat, Rasulullah mengutus sebuah pasukan berkuda ke suatu daerah. Namun, setelah sebulan lamanya tidak ada kabar dari pasukan tersebut. maka, turunlah ayat ini untuk memberitahu Rasulullah bagaimana keadaan pasukan tersebut saat itu (AlSuyūṭ̄ n.d.: 215). Keadaan pasukan tersebut tercermin dalam surah al-'Ádiyāt: 1-5. Keadaan pasukan tersebut, tergambar dalam surah al'-Ādiyāt, adalah pasukan yang sedang melakukan penyerangan ke dalam kelompok musuh. 
Kata wasatna dalam ayat ini dipahami oleh beberapa mufasir sebagai "menjadikan berada di tengah-tengah". Maka, yang dimaksud ayat 5 ini adalah kuda-kuda tersebut menyerbu ke tengah-tengah kelompok musuh secara mendadak, sehingga dengan begitu ia tiba-tiba telah berada di tengah-tengah musuh dan menjadikan musuh ketakutan dan porak-poranda (M. Q. Shihab 2002c: 542). Posisi penyerangan dari tengah-tengah kelompok musuh tersebut memiliki keuntungan tersendiri dibanding melakukan serangan dari luar. Keuntungan tersebut adalah memudahkan untuk menjangkau dan menaklukkan musuh secara menyeluruh dari dalam tanpa harus menembus semua pertahanan musuh.

\section{Penafsiran Wasathiyyah}

Definisi wasațhiyyah sudah banyak dibahas oleh para peneliti. Di antara mereka pun juga telah merumuskan sebuah definisi untuk memaknai wasațhiyyah ini. Namun, dalam penelitian ini, peneliti tidak akan menganalisis definisi-definisi yang telah mapan dari para tokoh, melainkan peneliti hendak menganalisis penafsiran Shihab yang termuat di dalam Tafsir Al-Misbah dengan harapan diperolehnya sebuah konsep wasatiyyah secara utuh menurut Shihab.

Ayat al-Qur'an yang oleh banyak penafsir dianggap yang paling ekplisit dalam menerangkan wasatiiyyah adalah QS. al-Baqarah [2] : 143. Dalam menafsiri ayat ini, Shihab menyatakan :

Dan demikian pula Kami telah menjadikan kamu wahai umat Islam "Ummatan Wasathan" (pertengahan) moderat dan teladan, sehingga dengan demikian keberadaan kamu dalam posisi pertengahan itu sesuai dengan posisi Ka'bah yang berada di pertengahan pula. Posisi pertengahan menjadikan manusia tidak memihak ke kiri dan ke kanan, suatu hal dapat mengantarkan manusia berlaku adil. Posisi pertengahan menjadikan seseorang dapat dilihat oleh siapa pun dalam penjuru yang berbeda, dan ketika itu ia dapat menjadi teladan bagi semua pihak (M. Q. Shihab 2002: 415).

Dari ungkapan tersebut, peneliti memahami bahwa wasatiyyah (yang disebut dalam al-Qur' an dengan ummatan wasatan atau disebut juga dengan "moderat") merupakan sikap pertengahan yang menjadi jalan utama bagi manusia untuk mencapai sebuah karakter yang mampu menjadikan manusia terbaik dengan bersifatkan adil dan menjadi teladan bagi orang-orang lain dalam setiap hal. 
Dengan kata lain, wasatiyyah merupakan sikap dan pola pikir yang mengantarkan umat Islam dapat menampakkan jati dirinya sebagai umat yang terbaik dan ideal.

Wasatiyyah merupakan ciri dari setiap ajaran Islam. Karena menjadi ciri, tentu saja wasațiyyah juga menjadi manifestasi dari setiap nilai-nilai kebajikan (kebaikan), karena ajaran Islam pun pasti mengajak pada kebaikan dan tidak pernah mengarah pada hal-hal yang negatif. Di lain sisi, sesuai definisi wasațiyyah yang merupakan sikap pertengahan, kebajikan pun juga merupakan pertengahan dari dua hal yang dianggap keterlaluan, baik terlalu baik atau terlalu buruk. $\mathrm{Hal}$ inilah yang peneliti pahami dari ungkapan Shihab dalam tafsirnya yang mencoba mencari titik tengah dalam memaknai arti ayat “" wo " yakni antara arti "yang terbaik atau yang biasa”. Dalam tafsirnya Shihab menyatakan:

Banyak ulama memahami kata (وسط) awsath/pertengahan dalam arti makanan yang bisa dimakan, bukan hidangan istimewa. Ada juga yang memahaminya dalam arti yang terbaik. Memang kata tersebut dapat juga diartikan demikian, tetapi pendapat pertama lebih kuat, apalagi salah satu ciri agama Islam adalah moderasi, bahkan kebajikan adalah pertengahan antara dua ekstrim. Bukankah kedermawanan adalah pertengahan antara sifat kikir dan boros (M. Q. Shihab 2002b: 233)

Dalam usahanya untuk menjelaskan prinsip wasațiyyah, setidaknya Shihab memberikan pengertiannya ke dalam tiga paradigma. Pertama, sikap wasațiyyah terkait pandangan terhadap dunia dan Tuhan. Shihab menjelaskn bagaimana posisi pertengahan dalam aspek kepercayaan dan religius. Dalam tafsirnya, Shihab menyatakan bahwa umat Islam harus meyakini wujud Tuhan yang tunggal dan mengingkari adanya paham politeisme, yakni meyakini adanya banyak tuhan. Tidak hanya itu, umat Islam juga harus bisa memadukan dan menyeimbangkan porsi pandangan dan aktivitasnya dalam ranah spiritualis dan materialis, tanpa adanya kecenderungan yang lebih terhadap salah satunya. Dalam hal ini, Shihab menyatakan:

Keberhasilan di akhirat ditentukan oleh iman dan amal saleh di dunia. Manusia tidak boleh tenggelam dalam materialisme, tidak juga memumbung tinggi dalam spiritualisme, ketika pandangan mengarah ke langit, kaki harus tetap berpijak di bumi. Islam mengajarkan umatnya agar meraih materi yang bersifat duniawi, tetapi dengan nilai-nilai samawi (M. Q. Shihab 2002a: 415). 
Kedua, wasathiyyah berarti posisi pertengahan sebagai poros teladan bagi banyak orang dari berbagai kalangan. Dengan posisinya yang berada di tengah, seseorang akan selalu tampak dan diperhatikan oleh banyak kalangan sehingga dengan begitu orang lain akan mudah menerima dan mengambil teladan dari orang tersebut. Posisi pertengahan pun juga memberikan keuntungan bagi umat Islam dalam usahanya memberi teladan, karena pertengahan adalah posisi yang paling strategis untuk melancarkan strategi. Tentunya, posisinya yang menjadi teladan tersebut harus selalu dilandasi dengan nilai-nilai yang diajarkan Nabi Muhammad. Hal ini seperti yang diungkapkan Shihab :

Posisi pertengahan menjadikan seseorang dapat dilihat oleh siapapun dalam penjuru yang berbeda, dan ketika itu ia dapat menjadi teladan bagi semua pihak. Posisi itu juga menjadikannya dapat menyaksikan siapa pun dan dimana pun. Allah menjadikan umat Islam pada posisi pertengahan agar kamu, wahai umat Islam, menjadi saksi atas perbuatan manusia yakni orang lain, tetapi ini tidak dapat kalian lakukan kecuali jika kalian menjadikan Rasul saw. syahid yakni saksi yang menyaksikan kebenaran sikap dan perbuatan kamu dan beliau pun kalian saksikan, yakni kalian jadikan teladan dalam segala tingkah laku (M. Q. Shihab 2002a: 415).

Ketiga, wasathiyyah berarti bersikap adil. Posisi pertengahan menjadikan sesorang mampu terbuka dalam berdialog dan berinteraksi dengan berbagai kalangan. Posisi yang berada di tengah membuatnya tdak akan berpihak ke kanan atau ke kiri, sehingga keadaan tersebut membuatnya tidak memihak secara membabi buta kepada salah satu pihak, dan tentunya hal ini menjadikannya dapat berbuat adil.

Berdasarkan uraian di atas, peneliti melihat setidaknya terdapat tiga hal yang selalu terkandung di dalam konsep wasațhiyyah. Ketiga hal tersebut adalah keadilan, toleransi dan keseimbangan. Keadilan menjadi dasar yang paling urgen. Adil berarti persamaan. Artinya tidak memihak pada salah satu pihak kecuali kepada pihak yang benar. Adil juga dapat berarti seimbang dan proporsional dalam memberikan hak-hak kepada masing-masing individu (M. Q. Shihab 1996: 114). Peneliti menggarisbawahi bahwa sifat adil sebagai salah satu dasar wasathiyyah ini membuat seseorang akan selalu memberikan hak-hak orang lain dengan cara yang tepat dan proporsional dengan tidak mengurangi atau melebih-lebihkannya. 
Selanjutnnya adalah toleransi. Terdapat dua unsur yang membentuk sikap toleransi, yakni adanya penyimpangan, baik berupa penambahan atau pengurangan dan adanya sikap menerima, membolehkan atau membiarkan penyimpangan tersebut (tidak memaksakan kehendak diri kepada orang lain). Dengan begitu, toleransi ini dimaknai sebagai sikap menerima adanya perbedaan kelakuan dari orang lain yang menurutnya telah menyimpang dan menyalahi dari yang semestinya. Namun demikian terdapat catatan bahwa penyimpangan tersebut harus lah masih dalam taraf yang dapat dimaklumi dan tidak keluar jauh dari batas-batas yang dapat dibenarkan (M. Q. Shihab 2002a: 668-669). Toleransi perlu dimiliki oleh setiap individu, karena setiap manusia hidup dalam kehidupan yang heterogen. Perbedaan adalah suatu keniscayaan. Adanya perbedaan tersebut membuat manusia rentan terhadap perpecahan dan dampak-dampak buruk lainnya. Oleh karena itu, sikap toleransi harus selalu tertanam dalam ruh masingmasing individu agar persatuan dan ketentraman hidup dapat tercapai.

Salah satu unsur pokok lain dalam wasațhiyyah adalah keseimbangan. Ia berperan penting dalam terwujudnya keadilan. Dalam keseimbangan terkandung makna "persamaan" porsi sesuai konteks antara dua bagian atau lebih yang bertolak belakangan. Dikatakan seimbang ketika antar bagian tersebut "dipersamakan" porsinya yang disesuaikan dengan faktor-faktor yang dapat menjadikan dua hal tersebut dapat "dipersamakan”. Dengan begitu, dalam upaya keseimbangan tidak harus terdapat kesamaan syarat dan kadar pada masing-masing bagian.

Salah satu pernyataan Quraish Shihab yang menganjurkan adanya keseimbangan antara materialisme dan spiritualisme dan juga mengaitkan keberhasilan di akhirat ditentukan dengan iman dan amal di dunia, tentu saja dalam pernyataan tersebut, seseorang tidak boleh menyamakan antara kehidupan dunia dan akhirat. Kehidupan akhirat jelas lebih baik sebagaimana QS. al-Dhuha [93]: 4. Meski demikian, tidak serta-merta membuat umat Islam harus terlalu fokus kepada urusan ukhrawi tanpa memedulikan urusannya duniawi, atau sebaliknya, karena terlena dengan dunia sehingga membuatnya lupa akan urusan akhirat kelak. Namun, sikap yang bijak adalah menyeimbangkan keduanya.

Faktor kenikmatan di dunia begitu menarik karena manusia merasakannya secara langsung, sedangkan rohaninya tidak dapat merasakan kenikmatan akhirat secara langsung. Oleh karena itu, manusia perlu memberikan penekanan lebih terhadap urusan akhiratnya agar tercipta keseimbangan dalam pandangan 
hidupnya. Dalam konteks kehidupan dunia, seseorang harus berusaha untuk mendapatkan penghidupan yang layak sebagai faktor untuk menggapai hidup yang makmur dan bahagia di dunia. Sedangkan dalam konteks akhirat, seseorang harus berusaha semaksimal mungkin dalam beribadah sebagai faktor untuk mendapat rida Tuhan dan surga-Nya.

Ide-ide wasathiyyah yang telah diungkapkan Shihab merupakan jalan tengah yang diambil untuk memberikan jalan keluar atas problematika yang terjadi. Peneliti melihat bahwa ide atau konsep wasațhiyyah Shihab ini merupakan kosep yang mencoba selalu berdialog dengan keadaan yang dilalui masing-masing individu, baik dalam segi sosial, ekonomi, budaya, pendidikan maupun akidah.

\section{Horizon Kekinian}

Saat ini, perkembangan gerakan Islam di Indonesia mengalami perubahan yang begitu signifikan. Dalam diri Islam mulai bermunculan pihak-pihak yang mencoba mengusik persatuan dan kesatuan umat Islam Indonesia, bahkan posisi NKRI sebagai suatu hal yang absolut pun juga mulai disangsikan. Pemikiranpemikiran liar yang mengatasnamakan agama Islam pun dijadikan senjata dalam melancarkan aksi tersebut. Keadaan ini merupakan buntut dari konflik WahabiSyiah yang sejak lama berkecamuk di Timur-Tengah yang perlahan juga merambah ke Indonesia. Imbas dari adanya konflik tersebut yang telah menyusup ke Indonesia, saat ini banyak ditemui mimbar masjid, ceramah, pengajian, kultum dan majelis yang berisi kajian Islam yang diisi sejumlah oknum yang mudah mengkafirkan, membid'ahkan, dan menganggap sesat orang lain yang tidak sejalan dengan pendapatnya. Tindakan demikian ini, secara tidak langsung juga menyumbang perpecahan umat Islam di Indonesia.

Dalam penerapan dalam horizon kekinian, peneliti melihat setidaknya terdapat dua peran penting konsep wasathiyyah Quraish Shihab, yakni berfungsi sebagai komponen dasar dalam menyelidiki fenomena-fenomena atau konflik sosialkeagamaan yang beredar dan sebagai upaya untuk meraih cita-cita hidup yang baik, selamat dan tentram di dunia serta di akhirat.

Konsep wasathiyyah Shihab memiliki keterlibatan secara praktis dalam membenahi kualitas moral dan kepribadian seseorang. Artinya, konsep wasathiyyah yang telah ditawarkan Shihab dipraktikkan sebagai perabot penyelidikan beberapa kasus tindakan tertentu yang dianggap ekstrem. Selain itu, konsep ini juga dapat dipraktikan sebagai bekal untuk menganalisis beberapa aspek 
yang telah menyebabkan munculnya masalah tersebut. Selain itu, konsep wasațhiyyah Shihab juga dijadikan sebagai panduan keselamatan dalam kehidupan di dunia dan akhirat. Sebagaimana yang dinyatakan Shihab bahwa keberhasilan manusia di akhirat ditentukan oleh iman dan amal saleh di dunia. Namun demikian, wasathiyyah Shihab mengarahkan seseorang untuk senatiasa seimbang dalam aspek spiritualisme dan materialisme.

Ungkapan Shihab tersebut menyiratkan makna, bahwa pola hidup yang baik di dunia dapat mengantarkan kesuksesan di dunia dan akhirat. Standar "pola hidup yang baik di dunia yang dimaksud adalah ketika seseorang telah beriman kepada Allah dan dalam praktek kehidupan dia dapat menyeimbangkan antara urusan dunia dan akhirat.

Lebih jelasnya, jika melihat pada QS. al-Baqarah: 143 yang telah lalu, dapat dipahami bahwa sikap wasatiiyyah dapat diimplementasikan pada era sekarang ini dengan selalu memelopori dan memrakarsai kebaikan-kebaikan untuk kemaslahatan hidup manusia, seimbang dalam pemahaman dan pengamalan prinsip kehidupan, baik dalam ranah sosial kehidupan maupun spiritual keagamaan, serta memenuhi dan menjalankan tanggung jawab dan kewajiban secara proporsional. Dengan demikian, setiap individu yang mengamalkan wasațiyyah ini akan dapat memberikan kesaksian atas umat lain sebagaimana yang telah disebutkan dalam ayat tersebut.

Selain itu, bersikap wasațiyyah juga berarti mampu mengidentifikasi hal-hal yang lebih diperioritaskan untuk dilaksanakan dibanding kepentingan-kepentingan lain serta menjaganya agar dapat terlaksana dengan baik. Makna ini tersirat dalam pemahaman dalam QS. al-Baqarah: 238. Tidak kalah pentingnya, implementasi wasațiyyah sebagaimana yang terkandung dalam QS. al-Mā'idah: 89 berarti juga harus meninggalkan amalan-amalan yang ifrāt (berlebih-lebihan dalam menjalankan agama) dengan terlalu memaksakan kehendak di luar kadar kemampuannya dan juga menjauhi sikap tafrit (menjalankan ajaran agama kurang dari semestinya). Yang semestinya adalah menjalankan agama sesuai dengan standar dan kemampuan masing-masing, tidak memaksakan diri dan juga tidak mengurangi ajaran agama dari yang semestinya.

Wasatiyyah juga mengarahkan tiap individu yang mengamalkannya untuk berpikir dinamis dan inovatif. Artinya, peran penting wasatiiyyah akan mampu mencetak individu yang terbuka dengan keadaan sekitar dan menyadari akan 
adanya hal-hal yang perlu dirubah atau bahkan menciptakan hal baru untuk mencapai kemaslahatan. Sikap ini sebagaimana yang tergambar dari kisah sekelompok pemuda yang diabadikan di dalam QS. al-Qalam: 28. Sementara itu, di dalam QS. al-'̄Adiyāt: 5 juga tercermin peranan wasațiyyah. Sebagaimana telah dijelaskan di muka, bahwa wasatiyyah merupakan posisi yang berada di tengah antara dua ekstremitas, maka posisi orang yang mengamalkan wasatiyyah membuatnya mampu bersikap egaliter dan tidak deskriminatif terhadap orang lain karena perbedaan status sosial, gender, keyakinan, tradisi, dan lain-lain. Karena posisinya yang berada di tengah dan tidak condong pada salah satu sisi ekstrem, maka membuatnya mudah merangkul dan menerima orang lain tanpa memandang sebelah mata dan tanpa adanya stereotip dan stigma negatif.

Dengan demikian, mengamalkan wasațiyyah dalam lingkup besar akan mampu melahirkan komunitas atau kelompok yang senantiasa mengedepankan kualitas moral dan akhlak serta prestasi-prestasi yang dapat membawa peradaban kehidupan ke arah yang lebih baik dan utama.

\section{Kesimpulan}

Penelitian wasațhiyyah dalam tafsir Al-Misbah dengan tinjauan analisis hermeneutika Hans-Georg Gamader menyimpulkan sebuah konsep. Dengan melihat rekam jejak kehidupan sosial keagamaan, pengalaman dan ilmu pengetahuan M. Quraish Shihab yang dibesarkan dalam lingkungan agamis dan menjunjung tinggi nilai-nilai agama Islam, peneliti menyimpulkan bahwa Shihab memandang wasațhiyyah sebagai ciri dari seluruh ajaran Islam yang berisikan kebajikan-kebajikan. Pengalaman hidup Shihab di satu sisi dalam melihat sejumlah fenomena yang terjadi pada umat Islam berdampak pada prapemahamannya dalam memahami wasathiyyah sebagai sikap pertengahan yang menengahi antara dua kubu ekstrem. Di sisi lain, horizon teks menyatakan bahwa wasathiyyah adalah posisi yang dapat mengantarkan manusia menjadi seorang teladan bagi orang lain. Dari peleburan horizon Shihab dan teks menghasilkan pandangan objektif konsep wasațhiyyah. Inti wasațiyyah adalah wujud keadilan, keseimbangan dan toleransi dalam setiap perilaku yang dijalani, baik secara vertikal maupun horizontal.

Dalam konteks kekinian, konsep wasațhiyyah Quraish Shihab dipandang sebagai ide solutif dalam menyelidiki dan meminimalisir adanya perpecahan umat. 
Untuk mewujudkan hal tersebut, maka diperlukan edukasi nilai-nilai wasathiyyah kepada segenap umat Islam dan masyarakat pada umumnya. Ini merupakan tanggung jawab besar para cendekiawan muslim dalam mentransfer nilai-nilai wasathiyyah sebagai sumbangan nyata dalam menjaga persatuan dan ketentraman antar umat. Demi terwujudnya cita-cita tersebut, setiap individu harus berkomitmen tinggi dalam mengamalkan nilai-nilai wasaţhiyyah dengan selalu mengutamakan kedamaian tanpa kekerasan, menjunjung tinggi toleransi, dan menjaga keutuhan bangsa dan kearifan lokal.

\section{DAFTAR PUSTAKA}

Adeni, and Nur Hamid. 2020. "Pergulatan Kelompok Civil Islam Arus Utama Dan Sempalan Dalam Ranah Private, Public, Market, Dan State: Pendekatan Sosiologis." International Journal Ihya' 'Ulum Al-Din 22(1): 71-94.

http://journal.walisongo.ac.id/index.php/ihya/article/view/5586.

Al-Suyūțī, 'Abd al-Raḥmān ibn Abī Bakr. Lubāb Al-Nuqūl Fī Asbāb Al-Nuzūl. Dar al-Kutub al-Ilmiyyah.

Amertawengrum, Indiyah Prana. 2010. “Teks Dan Intertekstualitas." MAGISTRA 22(73).

Anwar, Mauluddin, Latief Siregar, and Hadi Mustofa. 2015. Cahaya, Cinta, Dan Canda: M. Quraish Shihab. Tangerang: Lentera Hati.

Ghozali, Imam. 2020. "Memahami Format Demokrasi Model Khawarij Di Indonesia." Islamadina: Jurnal Pemikiran Islam 21(1): 17-25.

Harras, Muhammad Khalil. Syarh Al-Aqidah Al-Wasathiyyah. 4th ed. Ar-Risalah al-'Ammah li Idarah al-Buhus al-'Ilmiyyah wa al-Ifta' wa al-Da'wah wa alIrsyad.

HS, Muhammad Alwi, and Nur Hamid. 2019a. "Diskursus Kelisanan Al-Qur'an: Membuka Ruang Baru." Journal of Islamic Studies and Humanities 4(2): 262-82. http://journal.walisongo.ac.id/index.php/JISH/article/view/5232. . 2019b. "Relasi Kelisanan Al-Qur'an Dan Pancasila Dalam Upaya Menjaga Dan Mengembangkan Identitas Islam Indonesia." International Journal Ihya' 'Ulum Al-Din 21(1): 17-38. http://journal.walisongo.ac.id/index.php/ihya/article/view/4833.

Huda, Nur, and Athiyyatus Sa’adah Albadriyah. 2020. "Living Quran: Resepsi 
Al-Quran Di Pondok Pesantren Al-Husna Desa Sidorejo Pamotan Rembang." Al-Munqidz: Jurnal Kajian Keislaman 8(3): 358-76.

Irsyadunnas, Irsyadunnas. 2015. "Tafsir Ayat-Ayat Gender Ala Amina Wadud Perspektif Hermeneutika Gadamer." Musãwa Jurnal Studi Gender dan Islam 14(2): 123-42.

Junaidi, Mahabub. 2012. "Metode Interpretasi Al-Qur'an Menurut M. Quraish Shihab.” Kontemplasi: Jurnal Ilmu-Ilmu Ushuluddin 1(1).

Kathir, Ismail bin Umar Ibnu. 1999. 1 Tafsir Al-Qur'an Al-Azim. Dar AlTayyibah.

Mahsun, M S. 2014. Metode Penelitian Bahasa: Tahapan Strategi, Metode Dan Tekniknya. Jakarta: PT Raja Grafindo Persada.

Masduki, Mahfudz. 2009. Tafsir Al-Misbâh: Kajian Atas Amtsal Al-Qur'an. Yogyakarta: Pustaka Pelajar.

Muhammad bin Abdul Karim al-Syihristani. 1968. 1 Al-Milal Wa Al-Nihal. Syiria: Mu'assasah Al-Halabi.

Nata, Abuddin. 2004. Sejarah Pendidikan Islam: Pada Periode Klasik Dan Pertengahan.Jakarta: PT Raja Grafindo.

Qadir, Muhammad Al-Khair Abdul. 1999. Ittijahat Hadisah Fi Al-Fikr AlAlmani. Khurtum: Al-Dar al-Sudanuyyah li al-Kutub.

Rahmah, Mawaddatur. 2020. "Moderasi Beragama Dalam Al-Qur'an: Studi Pemikiran M. Quraish Shihab Dalam Buku Wasathiyyah: Wawasan Islam Tentang Moderasi Beragama." Pasca Sarjana UIN Sunan Ampel Surabaya.

Rohman, Ahmad Fadoli. 2020. "Studi Yuridis-Sosiologis Terhadap Problematika Perkawinan Sejenis Di Kantor Urusan Agama (KUA) Kecamatan Ajung Kabupaten Jember Tahun 2017.” Panangkaran: Jurnal Penelitian Agama dan Masyarakat 3(1): 51-69.

Rokhmad, Abu. 2018. "Buku Dan Penyebaran Ideologi Radikal Di Lembaga Pendidikan.” International Journal Ihya' 'Ulum al-Din 20(1): 41.

Said, Hasani Ahmad. 2014. Diskursus Munasabah Al-Qur'an Tinjauan Kritis Terhadap Konsep Dan Penerapan Munasabah Dalam Tafsir Al-Misbah. Jakarta: Lectura Press.

Shihab, Alwi. 1997. Islam Inklusif: Menuju Sikap Terbuka Dalam Beragama. Bandung: Mizan.

Shihab, M. Quraish. 1996. Wawasan Al-Quran: Tafsir Tematik Atas Pelbagai Persoalan Umat. Bandung: Mizan Pustaka. 
2002a. 1 Tafsir Al-Misbah: Pesan, Kesan Dan Keserasian Al-Qur’an. Jakarta: Lentera Hati.

___ 2002b. 3 Tafsir Al-Misbah : Pesan, Kesan Dan Keserasian Al-Qur`an. Jakarta: Lentera Hati.

____. 2002c. 15 Tafsir Al-Misbah : Pesan, Kesan Dan Keserasian Al-Qur’an. Jakarta: Lentera Hati.

___ 2019. Wasatiyah: Wawasan Islam Tentang Moderasi Beragama. Tangerang: Lentera Hati.

Siradj, Said Aqiel, and Mamang Muhamad Haerudin. 2015. Berkah Islam Indonesia: Jalan Dakwah Rahmatan Lil'Alam-in. PT Elex Media Komputindo.

Sumaryono, E. 2015. Hermeneutik: Sebuah Metode Filsafat. Yogyakarta: Kanisius.

Syamsudin, Sahiron. 2011. Hermenetika Hans-Georg Gadamer Dan Pengembangan Ulumul Qur'an Dan Pembacaan Alquran Pada Masa Kontemporer, Dalam Upaya Intergrasi Hermeneutika Dalam Kajian Qur'an Dan Hadis Teori Dan Aplikasi. 2nd ed. Yogyakarta: Lemlit UIN Suka.

Umam, Rozi El. 2018. “Konsep Islam Nusantara: Kajian Ayat-Ayat Multikultural Dalam Tafsir Al-Azhar Karya Hamka Dan Tafsir Al-Misbah Karya M. Quraish Shihab.” Pasca Sarjana UIN Sunan Ampel Surabaya.

Zamimah, Iffati. 2018. "Moderatisme Islam Dalam Konteks Keindonesiaan." AlFanar: Jurnal Ilmu Al-Quran Dan Tafsir 1(1): 75-90. 